\title{
PENGARUH SUHU PENGADUKAN TERHADAP YIELD BIODIESEL DARI MINYAK JELANTAH
}

\author{
Drajat Indah Mawarni \\ JurusanTeknikMesin \\ Sekolah Tinggi Teknologi Ronggolawe Cepu \\ Email: drajad_i@yahoo.com \\ Hendri Suryanto \\ JurusanTeknikMesin \\ Sekolah Tinggi Teknologi Ronggolawe Cepu \\ Email: hendrie_s@yahoo.com
}

\begin{abstract}
ABSTRAK
Biodiesel merupakan sumber energi alternatif pengganti minyak diesel, yang dapat dibuat dari senyawa tri gliserida dengan melalui proses reaksi transesterifikasi dengan menggunakan ethanol dan katalis KOH. Salah satu senyawa tri gliserida yang dapat digunakan sebagai bahan baku pembuatan biodiesel adalah minyak jelantah yang merupakan limbah minyak kelapa sawit. Parameter yang dapat digunakan sebagai tolok ukur dalam penelitian adalah jumlah yield biodiesel yang dihasilkan, dengan variasi suhu pengadukan. Variasi suhu pengadukan yang digunakan adalah $(40,45,50,55,60)^{\circ} \mathrm{C}$. Perbandingan molar ethanol yang digunakan dalam percobaan terhadap minyak jelantah adalah 6:1 dengan jumlah katalis $\mathrm{KOH}$ sebanyak $1 \%$ berat minyak jelantah. Sebelum proses transesterifikasi, dilakukan bleaching atau pemucatan dengan menggunakan karbon aktif sebanyak $7 \%$ dari berat minyak jelantah. Bleaching dilakukan dengan proses pengadukan dengan kecepatan $200 \mathrm{rpm}$ selama 1 jam. Setelah diendapkan dan disaring proses berikutnya adalah trasesterifikasi, yang dilakukan dengan mencampur minyak jelantah, ethanol dan katalis $\mathrm{KOH}$. Prosese transesterifikasi dilakukan melalui proses pengadukan dengan kecepatan putaran $200 \mathrm{rpm}$ selama 1 jam dan waktu pengendapan 24 jam pada berbagai perlakuan suhu pengadukan. Yield biodiesel tertinggi diperoleh pada pemanasan dengan suhu $50^{\circ} \mathrm{C}$ dengan nilai sebesar $76 \%$, dan yield biodiesel terendah diperoleh pada pemanasan dengan suhu $40^{\circ} \mathrm{C}$ dengan nilai sebesar $40 \%$.
\end{abstract}

Kata kunci: jelantah, yield, katalis, bleaching transesterifikasi.

\begin{abstract}
Biodiesel is an alternative energy source for diesel oil, which can be prepared from the tri-glyceride compound by the process of transesterification reaction using ethanol and $\mathrm{KOH}$ catalyst. One of the triglyceride compounds that can be used as raw material for making biodiesel is waste frying oilwhich is a waste of palm oil.Parameters that can be used as benchmarks in the study are the amount of yield of biodiesel produced, with variations of stirring temperature.Variation of stirring temperature used is $(40,45,50,55,60)^{\circ}$ C. The molar ratio of ethanol used in experiments against waste frying oil is 6: 1with a $\mathrm{KOH}$ catalyst amount of $1 \%$ by weight of waste frying oil.Prior to the transesterification, is a bleaching process that using active carbon $7 \%$ of the weight of waste frying oil.Bleaching is done by stirring process at $200 \mathrm{rpm}$ for 1 hour.After being precipitated and filtered the next process is trasesterification, which is done by mixing the waste frying oil, ethanol and $\mathrm{KOH}$ catalyst.Thetransesterification process is carried out by stirring process with a rotation speed of $200 \mathrm{rpm}$ for 1 hour and a 24-hour deposition time at various stirring temperature treatments. The highest biodiesel yield was obtained at heating at $50{ }^{\circ} \mathrm{C}$ with a value of $76 \%$, and the lowest biodiesel yield was obtained at a temperature of $40^{\circ} \mathrm{C}$ with a value of $40 \%$.
\end{abstract}

Keywords: waste frying oil, yield, katalis,bleaching transesterifikasi.

\section{PENDAHULUAN}

Energi fosil merupakan energi yang tidak dapat diperbarui, sehingga keberadaannya di alam semakin lama semakin habis. Sementara kebutuhan terhadap energi berbanding terbalik dengan ketersediaan energi yang ada. Sehingga untuk memenuhi kebutuhan energi diperlukan suatu upaya untuk 
mencari energi alternatif pengganti energi fosil. Berpijak pada Peraturan Presiden Republik Indonesia Nomor 5 Tahun 2006 tentang Kebijakan Energi, untuk mengembangkan energi alternatif pengganti BBM, maka berbagai upaya untuk melakukan diversifikasi energy dengan cara mencari energi alternatif yang terbarukan (renewable) dilakukan.

Bahan bakar alternatif yang dinilai layak sebagai pengganti minyak bumi yaitu bahan bakar yang berasal dari minyak nabati dan lemak hewani karena sifatnya sebagai sumber bahan bakar yang dapat diperbaharui, yang dikenal dengan metil ester atau biodiesel[1]Biodiesel merupakan bahan bakar diesel yang terbuat dari bahan hayati terutama lemak nabati dan lemak hewani[2]. Minyak goreng bekas merupakan salah satu bahan baku yang memiliki peluang untuk pembuatan biodiesel, karena minyak ini masih mengandung trigliserida, di samping asam lemak bebas[3]. Asam lemak dari minyak lemak nabati jika direaksikan dengan alkohol menghasilkan ester yang merupakan senyawa utama pembuatan biodiesel dan produk sampingan berupa gliserin yang juga bernilai ekonomis cukup tinggi. Gliserin ini dimanfaatkan untuk pembuatan sabun[4].Proses pembuatan biodiesel dapat dilakukan melalui tahap transesterifikasi dan perlakuan fisis seperti pemberian suhu proses dan lama waktu pengendapan. Oleh karena itu, penelitian untuk mengetahui seberapa besar pengaruh perlakuan fisis yang diberikan pada saat proses pembuatan biodiesel dari minyak jelantah sangat penting, sehingga dapat meningkatkan nilai guna minyak jelantah. Minyak jelantah yang sebelumnya hanya dibuang begitu saja akan lebih bernilai ekonomis bila diolah menjadi biodiesel untuk bahan bakar alternatif, disamping turut serta dalam mengelola dan memanfaatkan limbah serta dapat mengatasi kelangkaan BBM di masa depan. Beberapa faktor-faktor yang mempengaruhi proses transesterifikasi pada proses produksi biodiesel.

Homogenisasi campuran dalam reaksi mempengaruhi efektifitas reaksi karena tumbukan yang terjadi yang pada akhirnya akan mempengaruhi laju reaksi, konstanta reaksi, energi aktivasi dan lama reaksi. Transesterifikasi tidak akan berlangsung baik bila campuran bahan tidak dihomogenisasi terutama selama tahap awal proses. Pengadukan yang kuat (vigorous stirring) merupakan salah satu metode homogenisasi yang cukup berhasil untuk proses yang dilakukan secara batch dan kontinyu[2]

Rasio molar antara alkohol dan minyak nabati tergantung dari jenis katalis yang digunakan, untuk menjamin reaksi transesterifikasi berlangsung ke arah kanan maka direkomendasikan menggunakan katalis berlebih, perbandingan rasio molar $6: 1$ dari etanol terhadap katalis basa bisa digunakan untuk mendapat rendemen ester yang maksimum[5]atau sekitar 20\% etanol menghasilkan rendemen minyak biodiesel tertinggi pada perlakuan transesterifikasi[6].

Ethanol dan Metanol dapat menghasilkan ester lebih banyak dari pada etanol dan butanol[5]. Ethanol merupakan jenis alkohol yang banyak digunakan untuk proses transesterifikasi karena lebih reaktif dan dapat menghasilkan biodiesel 1,4 kali lebih banyak dibandingkan metanol[7]

Fungsi katalis dalam proses produksi biodiesel adalah untuk mempercepat reaksi dengan jalan menurunkan energi aktivasi (actifation energy, Ea). Proses produksi akan berlangsung sangat lambat dan membutuhkan suhu dan tekanan yang tinggi apabila tanpa menggunakan katalis [2]. Jika minyak mempunyai nilai FFA < 0,5\% maka bisa langsung diproses dengan transesterifikasi dengan katalis basa, namun apabila kandungan FFA > $5 \%$ maka proses harus dilakukan dengan Estrans(esterifikasitransesterifikasi)[5] dengan menggunakn katalis asam. Katalis asam seperti asam sulfat, asam phospat, asam klorida cocok untuk reaksi yang mempunyai bilangan asam lemak bebas tinggi[8]. Reaksi transesterifikasi menggunakan katalis basa dipengaruhi beberapa faktor yaitu internal dan eksernal. Faktor internal yaitu kualitas bahan baku minyak itu sendiri seperti kadar air serta asam lemak bebas yang sangat mempengaruhi reaksi. Faktor eksternal yaitu rasio mol antara alkohol dan minyak, jenis katalis, waktu reaksi, suhu, dan parameter-parameter lainnya pasca transesterifikasi[8].

Suhu selama reaksi transesterifikasi dapat dilakukan pada rentang suhu $30-65^{\circ} \mathrm{C}$ dan dijaga selama proses, tergantung dari jenis minyak yang digunakan[5]. Dalam proses transesterifikasi perubahan suhu reaksi menyebabkan gerakan molekul semakin cepat (tumbukan antara molekul pereaksi meningkat) atau energi yang dimiliki molekul bisa mengatasi energi aktivasi dengan kata lain perubahan suhu akan mempengaruhi probabilitas /peluang molekul dengan energi yang sama atau lebih tinggi dari energi aktivasi [9].

Lama waktu pengendapan berpengaruh pada proses tranesterifikasi dua tahap yaitu melakukan dua kali proses transesterifikasi[10]. Pengendapan bertujuan untuk memisahkan gliserol dan biodiesel. Waktu pengendapan metil ester mempengaruhi bilangan asam. Ketika pengendapan yang lebih lama, diduga tingkat oksidasi pada proses dua tahap lebih tinggi dari pada proses satu tahap. Hal ini mengakibatkan bilangan asam menjadi lebih tinggi [11].Umumnya,biodiesel cenderung mudah mengalami kerusakan oleh proses oksidasi dan hidrolisis pada waktu penyimpanan karena adanya asam lemak tak jenuh yang merupakan penyusun komposisi biodiesel

Keberadaan air yang berlebihan dapat menyebabkan sebagian reaksi dapat berubah menjadi reaksi sabun atau saponifikasi yang akan menghasilkan sabun, sehingga meningkatkan viskositas, terbentuknya gel dan dapat menyulitkan pemisahan antara gliserol dan biodiesel[12]. 
Keberhasilan proses pembuatan biodiesel dipengaruhi oleh putaran pengadukan[13]. Pengadukan bisa dilakukan menggunakan tangan serta alat seperti mixer[14]. Peningkatan kecepatan pengadukan reaksi berpengaruh sangat signifikan terhadap rendemen biodiesel yang dihasilkan, sedangkan kualitas biodiesel dipengaruhi secara signifikan oleh jenis pereaksi yang digunakan dan suhu reaksi[15].

Rendemen merupakan perbandingan berat biodiesel dengan berat minyak awal. Untuk menghitung rendemen biodiesel digunakan persamaan 1[16].

Rendemen $=\frac{\text { berat biodiesel }}{\text { berat minyak jelantah }} \times 100 \%$

\section{METODOLOGI PENELITIAN}

Penelitian ini merupakan penelitian eksperimen yang dilaksanakan di laboratorium Konversi Energi STTR Cepu mulai bulan Agustus s/d September 2017. Parameter yang digunakan adalah variasi suhu $40^{\circ} \mathrm{C}, 45^{\circ} \mathrm{C}, 50^{\circ} \mathrm{C}, 55^{\circ} \mathrm{C}$ dan $60^{\circ} \mathrm{C}$, dan lama waktu pengendapan (settling time) yang dilakukan selama 24 jam.

\subsection{Bahan Dan Alat}

Bahan yang digunakan untuk melakukan penelitian adalah minyak jelantah, karbon aktif, ethanol dan $\mathrm{KOH}$. Minyak jelantah yang digunakan adalah minyak sisa penggorengan dari hotel Ammy Cepu. Alat-alat yang digunakan dalam penelitian ini terdiri dari motor listrik, variable speed drive (VSD) inverter, blade untuk mengaduk, bejana, kompor listrik, saringan, tachometer danrak. Alat penelitian seperti ditunjukkan pada gambar berikut ini.

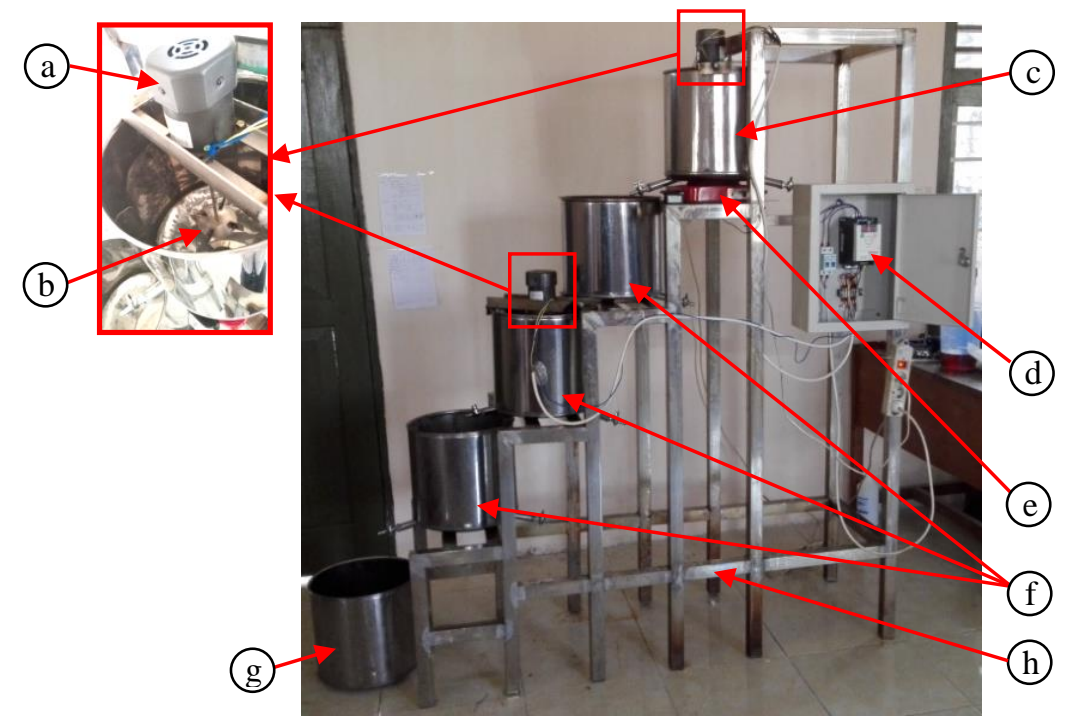

Gambar 1. Alat Penelitian, (a) Motor Listrik, (b) Blade, (c) Bejana Reaktor, (d) VSD Inverter, (e) Kompor Listrik, (f) Bejana Pencuci, (g) Bejana Penampung Biodiesel, (h) Rak

\subsection{Pretreatment}

Percobaan dimulai dengan proses bleaching (pemucatan) minyak jelantah dengan cara memanaskan pada suhu $70{ }^{\circ} \mathrm{C}$ disertai pengadukan dengan kecepatan putaran pengadukan $200 \mathrm{rpm}$ selama 1 jam dengan penambahan karbon aktif sebanyak $7 \%$ berat minyak jelantah. Kemudian minyak jelantah disaring dengan kertas saring untuk menghilangkan kotoran yang tersisa.

\subsection{Transesterifikasi}

Setelah melalui proses bleaching, berikutnya dilakukan proses transesterifikasi. Minyak jelantah yang sudah di bleaching, dimasukkan ke dalam tabung reaktor sebanyak 1996,80 g. Sementara itu, dipersiapkan larutan etanol (perbandingan molar etanol : minyak jelantah $=6: 1$ ) yang ditambahkan katalis $\mathrm{KOH}$ sebanyak $1 \%$ berat minyak jelantah. Campuran etanol dan katalis $\mathrm{KOH}$ disebut dengan senyawa metoksida. Pelaksanaan transesterifikasi dimulai dengan memanaskan minyak jelantah di dalam reaktor dengan variasi suhu pengadukan $(40,45,50,55,60)^{\circ} \mathrm{C}$. Setelah suhu tercapai, kemudian dimasukkan larutan 
metosida ke dalam reaktor, masih tetap diaduk dengan kecepatan pengadukan 200 rpm selama 1 jam. Setelah satu jam proses pengadukan, kemudian pengadukan dihentikan dan didiamkan selama 24 jam, hingga terbentuk dua lapisan. Lapisan atas berwarna kuning keemasan yang disebut biodiesel dan lapisan bawah berwarna merah kehitaman yang disebut dengan gliserin.

\subsection{Proses Pemisahan Dan Pemurnian}

Lapisan yang terbentuk, berikutnya dipisahkan, dengan cara dialirkan untuk ditampung dalam wadah secara manual. Lapisan atas adalah biodiesel dan lapisan bawah adalah gliserol. Selanjutnya diukur rendemennya.

\section{HASIL DAN PEMBAHASAN}

Proses pembuatan biodiesel dimulai dengan tahapan pretreatment. Pretreatment yang dilakukan adalah dengan melakukan pemucatan atau bleaching terhadap minyak jelantah dengan menggunakan karbon aktif. Volume karbon aktif yang digunakan adalah 7\% dari berat minyak jelantah. Proses pemucatan dilakukan dengan mencampur karbon aktif dan minyak jelantah dalam tangki pengadukan, berikutnya dilakukan pengadukan dengan kecepataan putaran pengadukan $200 \mathrm{rpm}$ pada suhu $70^{\circ} \mathrm{C}$ selama satu jam.

Minyak jelantah mengalami perubahan warna, yang semula berwarna merah kehitaman (gambar 2a), berubah menjadi coklat agak terang (gambar 2b). Perubahan warna pada minyak jelantah setelah di bleaching, disebabkan karena senyawa oksidasi yang terdapat di dalam minyak jelantah diikat oleh karbon aktif, karena karbon aktif berfungsi sebagai adsorber atau penyerap senyawa oksidasi yang terdapat di dalam minyak jelantah.

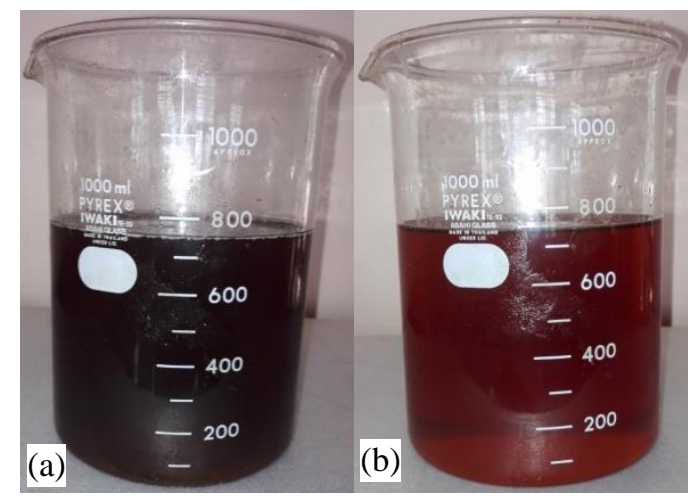

\section{Gambar 2. (a) Jelantah Sebelum Proses Bleaching, (b) Jelantah Setelah Proses Bleaching}

Setelah melalui proses bleaching, berikutnya proses transesterifikasi yang dilakukan dengan mencampurkan minyak jelantah yang telah di bleaching dengan larutan metoksida. Pembuatan larutan metoksida dilakukan dengan melarutkan katalis $\mathrm{KOH}$ ke dalam ethanol. Berikutnya mencampurkan larutan metoksida ke dalam minyak jelantah yang telah di bleaching. Minyak jelantah yang semula berwarna coklat agak terang, setelah dicampur dengan larutan metoksida, berubah menjadi coklat keruh. Proses transesterifikasi dilakukan dengan suhu pengadukan $(40,45,50,55,60){ }^{\circ} \mathrm{C}$, kecepatan putaran pengadukan $200 \mathrm{rpm}$ dan waktu pengadukan satu jam. Setelah satu jam pengadukan, proses pengadukan dihentikan lalu didiamkan selama24 jam, dan terbentuk dua lapisan. Lapisan di sebelah atas berwarna kuning terang yang disebut dengan biodiesel, sedangkan lapisan di bawahnya berwarna merah kehitaman, yang disebut dengan gliserin seperti ditunjukkan pada gambar 3.

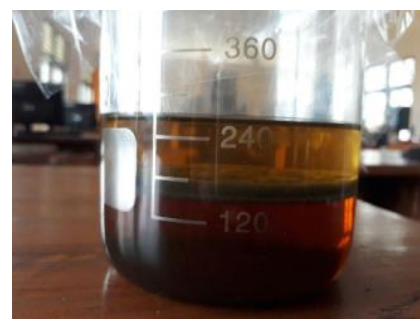

Gambar 3. Lapisan Biodiesel (Atas) Dan Gliserin (Bawah) 
Langkah berikutnya adalah menghitung rendemen biodiesel yang dihasilkan. Rendemen biodiesel dihitung dari jumlah biodiesel yang dihasilkan dibandingkan jumlah minyak jelantah mula-mula dikalikan seratus persen(persamaan 1). Hasil yang diperoleh kemudian ditabelkan sebagai berikut :

Tabel 1. Pengaruh suhu pengadukan terhadap rendemen biodiesel dari minyak jelantah

\begin{tabular}{lccccc}
\hline & \multicolumn{5}{c}{ Prosentase Yield / Rendemen Biodiesel terhadap suhu } \\
pengadukan
\end{tabular}

Masing-masing variasi suhu menghasilkan jumlah rendemen yang berbeda-beda. Berdasarkan tabel 1, pada suhu $50^{\circ} \mathrm{C}$ menghasilkan rendemen biodiesel yang paling besar adalah $76 \%$. Perbedaan rendemen tersebut disebabkan oleh beberapa hal yaitu, suhu dan ketelitian dalam menghomogenisasikan campuran antara bahan baku katalis dan alkohol. Pada awalnya hasil berat biodiesel yang didapatkan meningkat, akan tetapi, ketika suhu pemanasan optimum telah tercapai maka hasil berat biodiesel yang didapatkan menurun. Saat suhu proses $50^{\circ} \mathrm{C}$ bahan baku dari minyak jelantah sudah menerima panas yang maksimal untuk bereaksi dibanding dengan suhu lainnya. Dari percobaan yang telah dilakukan didapatkan hasil berat biodiesel optimum adalah pada suhu pemanasan $50^{\circ} \mathrm{C}$ waktu pemanasan satu jam.

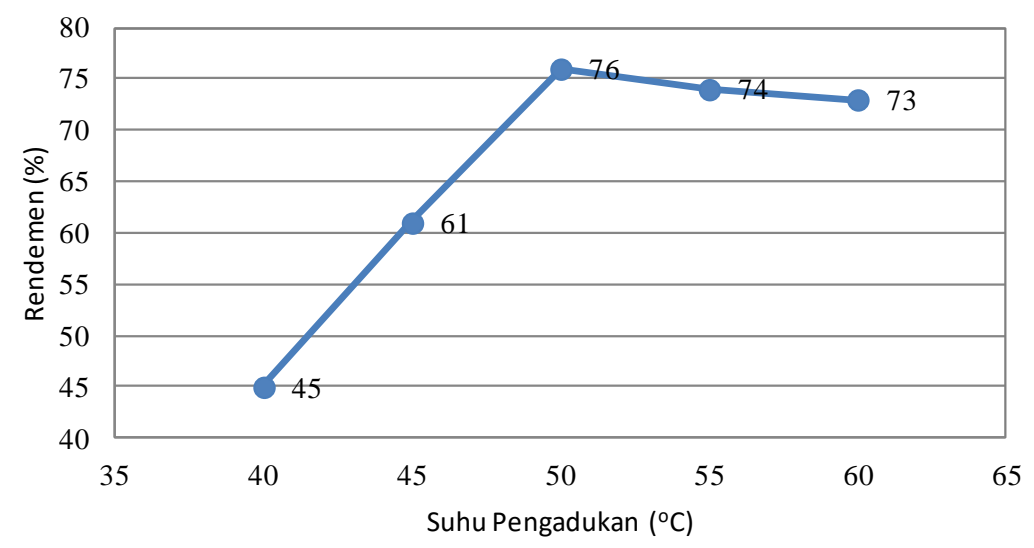

Gambar 4. Grafik Rendemen Terhadap Suhu Pengadukan

\section{KESIMPULAN}

Minyak jelantah dapat diubah menjadi biodiesel melalui proses transesterifikasi. Transesterifikasi dilakukan dengan rasio molar perbandingan minyak jelantah terhadap etanol adalah 1:6. Volume katalis $\mathrm{KOH}$ yang digunakan sebanyak $1 \%$ berat minyak jelantah. Pengaruh suhu pengadukan terhadap produk menunjukkan bahwa yield produk yang dihasilkan memiliki kecenderungan meningkat sampai titik tertinggi (optimum) kemudian akan turun kembali. Suhu optimal dicapai pada suhu $50^{\circ} \mathrm{C}$ dengan berat yield biodiesel $76 \%$ dan yield terkecil dicapai pada suhu $40^{\circ} \mathrm{C}$ dengan berat yield biodiesel $40 \%$.

\section{UCAPAN TERIMA KASIH}

Ucapan terima kasih kepada Kementerian Riset Teknologi dan Pendidikan Tinggi yang telah mendanai penelitian ini untuk skema Penelitian Dosen Pemula tahun 2017.

\section{DAFTAR PUSTAKA}

[1] Hambali,Erliza dkk.2007.TeknologiBioenergi.Agromedia. Jakarta.

[2] Darnoko, D, Cheryan M., 2000. Kinetics of Palm Oil Transesterification in Batch Reactor. J. Am. Oil Chem. Soc. 77:1263-1237.

[3] Darmawan, Ferry Indra dan I wayan Susila.2013.Proses Produksi Biodiesel dari Minyak Jelantahdengan Metode Pencucian Dry-WashSistem.JurusanTeknik Mesin UNESA.

[4] Arita, Susila., Tuti Emilia Agustina, Dina Patrica, \&Lena Rahmawati.2009.PemanfaatanGliserin Sebagai Produk Samping dari Biodiesel Menjadi Sabun Transparan.Jurnal Teknik Kimia, No. 4, Vol. 16, Desember. 
[5] Freedman, B, Pryde, E.H., Mounts,T.L,1986Variable Affecting the yield of fattyEstersfrom Transesterifikasi Vegetable Oils.JAOCS61,1638-1643.

[6] Hendra, Djeni.2014.PembuatanBiodieselDariMinyak Kemiri Sunan.Penelitian Hasil Hutan Vol. 32 No. 1, Maret: 37-45.

[7] Aziz,Islami.2007. Kinetika Reaksi Transesterifikasi Minyak Goreng Bekas.Valensi, Vol. 1, No.1.

[8] Van Gerpen, Jon. 2004. Biodiesel Production and Quality. Department of Biological and Agricultural Engineering. University of Idaho. Moscow.

[9] Kartika,Dwi dan Senny Widyaningsih.2012.Konsentrasi Katalis dan Suhu Optimum pada Reaksi Esterifikasi menggunakan Katalis Zeolit Alam Aktif (ZAH) dalam Pembuatan Biodiesel dari Minyak Jelantah.Jurnal Natur Indonesia 14(3), Juni: 219-226.

[10] Rengga, Wara Dyah Pita, \&Wenny Istiani.2011.SintesisMetil Ester dari MinyakGoreng Bekasdengan Pembeda Jumlah Tahapan Transesterifikasi.Jurnal Kompetensi Teknik Vol. 2, No. 2, Mei.

[11] Canakci, M., A. Monyem,\& J. Van Gerpen. 1999. Accelerated Oxidation Processes In Biodiesel. VOL. 42(6): 1565-1572.

[12] Fukuda, H., Kondo, A., \& Noda, H. 2001. Biodiesel Fuel Production by Transesterification of Oil.Jou of Bios and Bioeng 92 : 405-416.

[13] Darmanto, S. (2010). "Analisa Karakteristik Biodiesel Kapuk Randu sebagai Bahan Bakar Mesin Diesel", Jurnal Teknik Energi, Vol 6, No. 3.

[14] Manai, Syamsuddin.2010. Membuat Sendiri BiodieselBahan Bakar Pengganti Solar. Penerbit Andi. Yogyakarta.

[15] Kartika, I. A., Yani, M. dan Hermawan, D. 2011. Transesterifikasi In Situ Biji Jarak Pagar:Pengaruh Jenis Pereaksi, Kecepatan Pengadukan dan Temperatur Reaksi Terhadap Rendemen dan Kualitas Biodisel. J. Tek. Ind. Pert. 21: 24-33.

[16] Zuhra, Husni Husin, Fikri Hasfita, dan Wahyu Rinaldi.2015. Preparasi Katalis Abu Kulit Kerang Untuk Transesterifikasi Minyak Nyamplung Menjadi Biodiesel.Journal AGRITECH, Vol. 35, No. 1, Februari.[ (2011) 1751-1761. 